\title{
PROSEDUR PEMBUKAAN REKENING TABUNGAN DAN REALISASI PENERIMAAN TABUNGAN PADA LEMBAGA PERKREDITAN DESA (LPD) DESA PAKRAMAN BONDALEM TAHUN 2013-2014
}

\author{
Komang Putri Sudiadnyani \\ Jurusan Akuntansi Program Diploma III, \\ Universitas Pendidikan Ganesha, Singaraja \\ e-mail : aniwardana17@gmail.com
}

\begin{abstract}
Abstrak
Penelitian ini bertujuan untuk mengetahui bagaimana prosedur pembukaan rekening tabungan dan realisasi penerimaan tabungan pada LPD Desa Pakraman Bondalem. Teknik pengumpulan data yang digunakan yaitu metode wawancara dan metode dokumentasi. Subjek penelitian adalah LPD Desa Pakraman Bondalem dan objek penelitian adalah prosedur pembukaan rekening tabungan dan realisasi penerimaan tabungan. Jenis data yang digunakan adalah data kuantitatif dan kualitatif. Selanjutnya data akan dianalisis dengan analisis deskriptif kualitatif dan kuantitatif.

Hasil penelitian menunjukkan bahwa (1) prosedur pembukaan rekening tabungan pada LPD Desa Pakraman Bondalem sudah sesuai dengan standar operasional prosedur pada LPD yang telah ditetapkan dan (2) realisasi penerimaan tabungan pada tabungan SIMADE mengalami penurunan diakibatkan karena tingkat suku bunga yang terlalu besar diantara produk tabungan yang lainnya dan penarikannya dilakukan setahun sekali, sedangkan pada tabungan SUKARELA dan Simpanan Berjangka (DEPOSITO) selalu mengalami kenaikan disebabkan karena tingkat suku bunga pada kedua program tabungan tersebut masih relatif rendah dan penarikannya bisa dilakukan sewaktuwaktu.
\end{abstract}

Kata Kunci : Prosedur Pembukaan Rekening Tabungan, Realisasi

This study is aimed at investigating the procedure of opening a saving account and the realization of saving acceptance in LPD Desa Pakraman Bondalem. The techniques of data collection used are interview method and documentation method. The subject of this study is LPD Desa Pakraman Bondalem and the object of this study is the procedure of opening a saving accountand the realization of saving acceptance. The type of data that will be analyzed are quantitative and qualitative data. Afterwards, the data will be analyzed with quantitative and qualitative descriptive analysis.

The result of this study shows that (1) the procedure of opening a saving account in LPD Desa Pakraman Bondalem is in a line with the agreed procedural standard in LPD(2) the realization of saving acceptance in SIMADE saving faces a decreasing, which is caused bythe high rate of interest among other kinds of saving products and the withdrawl can only be done once a year, while the rate of the voluntary saving (Tabungan Sukarela) and the time saving (Deposit) always rises, caused by the low rate of interest on both those saving programs and the withdrawl can be conducted anytime

Keywords: The Procedure Of Opening A Saving Account, Realization

\section{Pendahuluan}

Pembangunan nasional suatu bangsa mencakup di dalamnya pembangunan ekonomi. Pembangunan ekonomi tersebut tentu sangat tergantung pada perkembangan dan peranan dari lembaga keuangan baik lembaga keuangan bank maupun lembaga keuangan non bank. Salah satu lembaga keuangan non bank yang terdapat di Bali adalah Lembaga Perkreditan Desa (LPD). Lembaga Perkreditan Desa (LPD) Desa Pakraman Bondalem termasuk dalam lembaga keuangan non bank yang terdapat di Provinsi Bali. Salah satu jasa yang diberikan dari LPD Desa Pakraman Bondalem adalah pembukaan rekening tabungan. Dalam pembukaan rekening tabungan sangat diperlukan adanya prosedur dikarenakan agar para nasabah yang ingin membuka rekening tabungan bisa mengetahui tahapan-tahapan 
pembukaan rekening tabungan. Jika prosedur dalam pembukaan rekening tabungan berjalan dengan efektif dan efisien, maka realisasi penerimaan tabungan akan mengalami peningkatan. Peningkatan ini akan berdampak ke peningkatan sumber dana yang dapat digunakan lebih banyak lagi oleh LPD Desa Pakraman Bondalem dalam menyalurkan kredit ke masyarakat. Selain adanya prosedur yang baik untuk menarik minat masyarakat untuk membuka rekening tabungan, LPD Desa Pakraman Bondalem harus mampu menghimpun dana secara efektif dengan memberikan bunga yang sudah ditetapkan oleh LPD itu sendiri. Hal lain yang perlu menjadi perhatian pihak LPD Desa Pakraman Bondalem adalah LPD harus memiliki rencana atau anggaran dan realisasi kerja penerimaan tabungan dari tahun ke tahun, guna mengetahui perkembangan tabungan, apakah mengalami peningkatan atau mengalami penurunan. Dengan adanya rencana dan realisasi kerja penerimaan tabungan maka LPD Desa Pakraman Bondalem akan mengetahui bagaimana tingkat perkembangan penerimaan tabungan yang direncanakan dan realisasinya, sehingga dapat disusun langkahlangkah atau rencana yang dapat merealisasikan rencana peningkatan tabungan yang sudah ditetapkan sebelumnya.

\section{Metode Penelitian}

Penelitian ini dilakukan pada Lembaga Perkreditan Desa (LPD) Desa Pakraman Bondalem yang beralamat di Desa Bondalem, Kecamatan Tejakula, Kabupaten Buleleng.Adapun yang menjadi subyek dari penelitian ini adalah Lembaga Perkreditan Desa (LPD) Desa Pakraman Bondalem, sedangkan objek dari penelitian ini adalah prosedur pembukaan rekening tabungan dan realisasi rencana penerimaan tabungan tahun 20112013. Berdasarkan jenis data, jenis data yang digunakan adalah Data Kuantitatif yaitu data yang dapat dihitung berupa angka-angka, seperti jumlah rencana dan realisasi penerimaan tabungan tahun 2013-2014 pada Lembaga Perkreditan Desa (LPD) Desa Pakraman Bondalem dan Data

Kualitatif yaitu data yang berbentuk kata, kalimat dan gambar yang diperlukan dalam uraian uraian yang sifatnya sebagai penunjang dalam pembahasan, seperti wewenang dari masing masing bagian, dan prosedur pembukaan rekening tabungan.

Berdasarkan penelitian, sumber data yang digunakan adalah Data Primer yaitu data yang diperoleh langsung dari sumbernya yaitu dari Karyawan Lembaga Perkreditan Desa (LPD) Desa Pakraman Bondalem wawancara mengenai prosedur pembukaan rekening tabungan dan informasi-informasi lainnya yang berhubungan dengan penelitian dan Data Sekunder yaitu data yang diperoleh dari dokumen-dokumen seperti realisasi penerimaan tabungan pada LPD atau buku-buku yang berhubungan dengan realisasi penerimaan tabungan pada LPD.

Metode yang digunakan dalam penelitian ini ada 2 macam yaitu : Metode Dokumentasi yaitu pengmpulan data yang diperoleh dengan mencari informasi atau data melalui arsip dan dokumentasi, seperti data realisasi penerimaan tabungan tahun 2013-2014 dan Data Sekunder yaitu data yang diperoleh dari dokumen-dokumen seperti realisasi penerimaan tabungan pada LPD atau buku-buku yang berhubungan dengan realisasi penerimaan tabungan pada LPD.

Teknik analisis data yang digunakan dalam penelitian ini adalah analisis deskriptif kualitatif dan deskriptif kuantitatif. Analisis deskriptif kualitatif yaitu prosedur penelitian berdasarkan data deskriptif, yaitu berupa lisan dan kata tertulis deri seseorang subjek yang telah diamati dan memiliki karakteristik bahwa data yang diberikan merupakan data asli yang tidak diubah serta menggunakan cara sistematis dan dapat dipertanggungjawabkan (Sugiyono, 2013:23).Teknik analisis deskriptif kualitatif tersebut dilakukan dengan menguraikan dan mendeskripsikan tentang prosedur pembukaan rekening tabungan sedangkan analisis deskriptif kuantitatif yaitu suatu metode penelitian yang dilakukan untuk mengungkapkan kebenaran dari sebuah teori (Sugiyono, 2013:23). Analisis deskriptif kuantitatif tersebut di lakukan untuk memaparkan data yang diperoleh dan mengelola data 
tersebut untuk menghitung persentase pencapaian target penerimaan tabungan terhadap rencana penerimaan tabungan yang telah ditetapkan sebelumnya.

hasil dari analisis ini akan digunakan sabagai dasar kesimpulan penelitian terkait dengan prosedur pembukaan rekening tabungan dan realisasi penerimaan rekening tabungan tahun 2013-2014 di LPD Desa Pakraman Bondalem.

\section{Hasil dan Pembahasan}

Adapun formulir yang digunakan dalam Prosedur Pembukaan Rekening Tabungan pada LPD Desa Pakraman Bondalem sebagai berikut :

a. Formulir Pembukaan Rekening Tabungan (PRT), yang diminta dan diisi oleh calon nasabah untuk memohon pembukaan rekening tabungan

b. Formulir Fotocopy Kartu Tanda Penduduk (KTP), formulir data diri yang dibawa oleh calon nasabah saat mengisi formulir pembukaan rekening tabungan.

Bagian yang terlibat dalam prosedur pembukaan rekening tabungan pada LPD Desa Pakraman Bondalem yaitu Bagian Tabungan . diawali dari kedatangan calon nasabah meminta dan mengisi formulir pembukaan rekening tabungan berdasarkan dari dokumen yang dibawa oleh calon nasabah berupa fotocopy Kartu Tanda Penduduk (KTP). Setelah mengisi formulir pembukaan rekening tabungan tersebut, formulir pembukaan rekening tabungan yang berisi lampiran fotocopy Kartu Tanda Penduduk (KTP) dberikan kepada Bagian Tabungan, kemudian Bagian Tabungan mencatat nama calon nasabah kedalam buku register tabungan yang dilanjutkan dengan memberikan nomor rekening tabungan serta cap LPD pada buku rekening tabungan tersebut. Dokumen seperti formulir pembukaan rekening tabungan dan fotocopy Kartu Tanda Penduduk (KTP) diarsip oleh Bagian Tabungan sebagai arsip bukti pembukaan rekening tabungan. Kemudian, buku rekening tabungan yang sudah jadi diserahkan kepada nasabah.

Dari data mengenai rencana dan realisasi penerimaan tabungan tahun anggaran 2013-2014, dapat diketahui hal-hal sebagai berikut:

a. Untuk Tabungan SIMADE, rencana penerimaan tabungan tahun 2013 sebesar Rp.620.135.000 dan realisasinya sebesar $\mathrm{Rp}$. 456.643.103 jadi presentasenya sebesar 73,64 \%. Kemudian untuk tahun 2014, rencana penerimaan Tabungan SIMADE sebesar Rp.630.000.000 dan realisasinya sebesar Rp. 599.505.207 Jadi presentasenya sebesar $95,2 \%$.

b. Untuk Tabungan Sukarela, rencana penerimaan tabungan tahun 2013 sebesar Rp. 12.283.589.000 dan realisasinya sebesar Rp. 13.372.854.337, jadi presentasenya sebesar 108,9\%. Kemudian untuk tahun 2014, rencana penerimaan Tabungan Sukarela adalah sebesar Rp.14.102.500.000 dan realisasinya adalah sebesar Rp. 15.054.660.292, jadi presentasenya sebesar 106,75\%.

c. Untuk Simpanan Berjangka (Deposito), rencana penerimaan tabungan tahun 2013 adalah sebesar Rp. 9.971.446.000 dan realisasinya sebesar Rp.14.417.556.000, jadi presentasenya sebesar 144,6\%. Kemudian untuk tahun 2014, rencana penerimaan Simpanan Berjangka adalah sebesar Rp.16.002.500.000 dan realisasinya sebesar Rp. 17.772.950.000 jadi presentasenya sebesar 111,1.

LPD Desa Pakraman Bondalem dalam menjalankan prosedur pembukaan rekening tabungan memegang prinsip kehati-hatian agar nantinya tidak menimbulkan masalah yang dapat merugikan pihak LPD terutama ketika melakukan pembukaan rekening tabungan.

Dalam implementasinya, prosedur pembukaan rekening pada LPD Desa Pakraman Bondalem dalam membuka rekening tabungan sudah sesuai dengan standard operating procedure (SOP), itu semua dapat dilihat dari proses pembukaan rekening tabungan dan tahapan-tahapan pembukaan rekening tabungan sudah diikuti oleh nasabah dengan baik didukung dengan dokumen-dokumen yang dapat mendukunng proses pembukaan rekening tabungan, serta dipatuhinya tahapan pelaksanaan prosedur pembukaan rekening tabungan oleh LPD Desa Pakraman Bondalem sesuai dengan tahapan yang dibuat oleh LPD Desa Pakraman Bondalem itu sendiri. Selain itu, pelayanan pembukaan rekening tabungan yang 
diberikan kepada masyarakat oleh LPD Desa Pakraman Bondalem sudah optimal terlihat dari respon positif masyarakat desa dengan lancarnya proses pembukaan rekening tabungan yang telah mengalami peningaktan minat masyarakat untuk menabung di LPD Desa Pakraman Bondalem.

Realisasi penerimaan tabungan disini guna mengetahui perkembangan produk-produk tabungan yang dimiliki, apakah mengalami kenaikan ataukah mengalami penurunan dan apa penyebab meningkat dan menurunnya setiap produk tabungan. Realisasi penerimaan tabungan pada LPD Desa Pakraman Bondalem ditetapkan oleh Kepala LPD Desa Pakraman Bondalem dengan melihat presentase penerimaan tabungan dari tahun sebelumnya.

Realisasi penerimaan tabungan tahun anggaran 2013 dapat dilihat bahwa rencana penerimaan untuk program Tabungan SIMADE pada tahun anggaran 2013 mengalami penurunan sebesar Rp. 163.491.897 dan tahun anggaran 2014 sebesar Rp. 30.494.793. Tabungan SIMADE tidak berhasil mencapai target yang di tetapkan atau direncanakan, hal ini disebabkan karena program tabungan SIMADE hanya bisa melakukan penarikan dalam jangka waktu 1 (satu) tahun meskipun program tabungan SIMADE memiliki tingkat suku bunga paling tinggi yaitu sebesar $0,80 \%$. Selanjutnya untuk tabungan sukarela tahun anggaran 2013 mengalami kenaikan sebesar Rp.1.089.265.337 dan tahun anggaran 2014 juga mengalami kenaikan sebesar Rp. 952.160.292. Tabungan sukarela berhasil mencapai target yang direncanakan. Peningkatan target yang dicapai oleh Tabungan Sukarela dikarenakan program tabungan sukarela dapat ditarik sewatu-waktu oleh nasabah. Untuk Simpanan Berjangka (deposito) berhasil mencapai target yang telah ditetapkan dengan mengalami kenaikan sebesar Rp. 5.371.883.440 pada tahun anggaran 2013 dan tahun anggaran 2014 mengalami kenaikan sebesar Rp. 1.770.450.000. Program tabungan ini berhasil mencapai target dikarenakan dalam program Simpanan Berjangka suku bunga yang di dapat lebih besar dari pada suku bunga harian dan tidak bisa diambil setiap saat atau sewaktu-waktu.

\section{Simpulan dan Saran}

Dari hasil penelitian dan pembahasan diatas, dapat ditarik kesimpulan bahwa dalam pelaksanaannya, prosedur pembukaan rekening tabungan yang dijalankan oleh Lembaga Perkreditan Desa (LPD) Desa Pakraman Bondalem sudah baik dan telah sesuai dengan Standar Operasional Prosedur (SOP) LPD Desa Pakraman Bondalem yang telah ditetapkan.

Realisasi penerimaan tabungan tentu memiliki peningkatan dan penurunan. Dalam LPD Desa Pakraman Bondalem untuk tahun anggaran 2013, bisa dilihat bahwa Tabungan SIMADE tidak dapat mencapai target yang telah direncanakan karena tabungan SIMADE hanya bisa di tarik dalam jangka waktu 1 tahun, sedangkan untuk produk Tabungan Sukarela dan Simpanan Berjangka (Deposito) berhasil mencapai target yang telah ditetapkan. Untuk Tabungan Sukarela berhasil mencapai target dikarenakan bisa di tarik sewaktu-waktu dan Simpanan Berjangka juga mengalami peningkatan karena walaupun tidak dapat ditarik sewaktu-waktu tetapi deposito memiliki suku bunga lebih besar daripada suku bunga harian.

Berdasarkan hasil penelitian dan kesimpulan diatas, adapun saran yang dapat diberikan adalah Pihak Lembaga Perkreditan Desa (LPD) Desa Pakraman Bondalem konsisten dalam menerapkan prosedur yang telah ditetapkan untuk meminimalisir kesalahan-kesalahan yang tidak diinginkan sehingga kesalahan dalam proses pembukaan tabungan dapat diminimalisir.

Selain itu, Lembaga Perkreditan Desa (LPD) Desa Pakraman Bondalem harus meningkatkan kinerja dalam merealisasikan rencana penerimaan tabungan, sehingga apa yang direncanakan bisa direalisasikan guna mencapai apa yang menjadi tujuan LPD Desa Pakraman Bondalem, dan Pihak LPD sebaiknya menambah program baru yang bisa menarik minat dari masyarakat dan lebih gencar mempromosikan program-program yang dimiliki LPD 
Desa Pakraman Bondalem. Misalnya program-program terkait dengan pendidikan atau kesehatan atau pertanian yang terkait dengan kehidupan masyarakat di Desa Bondalem.

\section{Daftar Pustaka}

Arthesa, Ade, dkk. 2009. Bank dan Lembaga Keuangan Bukan Bank. Cetakan II. Jakarta : PT Indeks.

Arikunto, Suharsimi. 2005. Manajemen Penelitian. Edisi Revisi. Jakarta. PT Rineka Cipta Baridwan, Zaki dan W. Gerald Cole. 1998. Sistem Akuntasi. Yogyakarta : BPFE Yogyakarta. Kasmir. 2001. Bank \& Lembaga Keuangan Lainnya. Edisi Revisi. Jakarta : PT Raja Grafindo. Kasmir. 2003. Dasar-dasar Perbankan. Jakarta: PT. Grafindo Persada.

Lapoliwa, N dan Daniel S. Kuswandi. 2002. Akuntansi Perbankan (Transaksi Bank Dalam Valuta Rupiah). Edisi 5. Jakarta : Institut Bank Indonesia.

Munandar, M. Budgeting. Edisi Pertama. Yogyakarta : BPFE Yogyakarta.

Mulyadi. 1997. System Akuntansi. Edisi Ketiga. Yogyakarta : Bagian Perbitan S YKPN

Pertamawati, Ni Putu. 2010. "Pemberdayaan Lembaga Perkreditan Desa (LPD) Dalam Mendorong Penggalian Dana Pembangunan Pedesaan di Provinsi Bali”. Sarathi Vol.15 No.1 Januari 2008.

Santoso. 1995. Pengertian Tabungan. Cetakan II. Jakarta : PT Indeks.

Undang-undang Peraturan Daerah No.2/1988 dan No 8 Tahun 2002 Tentang Tujuan Secara Umum Lembaga Perkreditan Desa

Undang-undang Peraturan Daerah Provinsi Bali Nomor 8 Tahun 2002 Pasal 1 Butir 11 Tentang Pengertian Lembaga Perkreditan Desa : https://www.google.co.id 